\title{
INTERNALISASI NILAI TAUHID DALAM PEMBELAJARAN SAINS
}

\author{
Ayi Darmana \\ Universitas Negeri Medan -UNIMED \\ Jl. Willem Iskandar Pasar V Medan 20221 Sumatera Utara \\ E-mail : adarmana@yahoo.com
}

\begin{abstract}
ABSTRAK
Kajian model hipotesis internalisasi nilai tauhid dalam materi sains (fakta, konsep, dan hukum) diharapkan dapat meningkatkan kontribusi relatif pembelajaran sains terhadap ketercapaian tujuan pendidikan nasional. Internalisasi nilai tauhid pada materi sains tidak akan mengurangi kadar keilmiahan sains itu sendiri. Bahkan, kajian ini dapat meningkatkan kualitas materi sains. Sains sebagai sarana untuk mengembangkan potensi kognitif, sains pun dapat menumbuhkan potensi nurani (afektif). Materi sains ini akan mampu menanamkan keyakinan tentang segala sesuatu yang ada di alam. Segala sesuatu yang hakikatnya diciptakan Allah, Tuhan Yang Maha Esa. Keyakinan ini dapat mendorong terhadap keyakinan tentang ketundukan, karakteristik dan keteraturan dari benda-benda yang Allah ciptakan (sunatullah), sehingga manusia dapat mempelajarinya. Semua ini akan memungkinkan tumbuhnya sikap positif, kagum akan kebesaran, kekuasaan dan kasih sayang Allah, menjadi motivasi untuk bersyukur, meningkatkan keimanan dan ketaqwaan kepada Allah yang Maha Kuasa. Internalisasi nilai tauhid pada materi sains dapat dilakukan melalui pengungkapan nilai/hikmah/makna/hakikat dari materi sains tersebut berdasarkan sudut pandang Islam.
\end{abstract}

Kata kunci : Tauhid, Internalisasi, Materi sains.

\begin{abstract}
The study on bypothesis model of internalizing tawheed values in science materials (facts, concepts, and law) is expected to increase relative constribution of learning science toward achieving the national education objectives. The internalization will not lessen the scientifics itself. As a media to develop cognitive potency, science could develop the affective one as well. Through the materials, science internalizes the belief regarding all things in this world: things Allah has created, This belief could lead us to the obidience, characteristics and regularity of those things God created (Sunatullah), so that people can learn from them. It would enable the development of positive attitude, admiration to God's power and love, gatitude and loyalty to Him. The internalization of tawheed values in science materials can be done through the discussion on the value/moral lesson/ nature of the material from Islam perspective.
\end{abstract}

Keywords: Tawheed, internalization, science materials 


\section{PENDAHULUAN}

UUD 1945 pasal 31 ayat 3, pendidikan nasional bertujuan untuk meningkatkan keimanan dan ketaqwaan kepada Tuban Yang Maha Esa serta ahlak mulia dalam rangka mencerdaskan kehidupan bangsa. Undang-undang tersebut mengindikasikan arti bahwa pendidikan di Indonesia pada hakikatnya adalah untuk membentuk manusia Indonesia yang berkualitas dan memiliki kinerja yang baik. Menurut UUSPN No. 2 Tahun 1989, manusia Indonesia yang berkualitas yaitu manusia yang beriman dan taqwa terhadap Tuhan yang Maha Esa, berbudi pekerti luhur, berkepribadian, berdisiplin, bekerja keras, tangguh, bertanggung jawab, mandiri, cerdas dan terampil, serta sehat jasmani dan rohani, cinta terhadap tanah air dan akan bangsa dan negara serta memiliki kesetiakawanan sosial yang tinggi.

Penjelasan tujuan pendidikan lebih lanjut dinyatakan dalam UUSPN no. 20 tahun 2003 pasal (1), bahwa pendidikan adalah usaha sadar dan terencana untuk mewujudkan suasana belajar dan proses pembelajaran agar peserta didik secara aktif mengembangkan potensi dirinya untuk memiliki kekuatan spiritual keagamaan, pengendalian diri, kepribadian, kecerdasan, akhlak mulia, serta keterampilan yang diperlukan dirinya dan masyarakat. UUSPN No. 20 Tahun 2003 Pasal (3), pendidikan nasional berfungsi mengembangkan kemampuan dan membentuk watak serta peradaban bangsa yang bermartabat dalam rangka mencerdaskan kehidupan bangsa, bertujuan untuk mengembangkan potensi peserta didik agar menjadi manusia yang beriman dan bertakwa kepada Tuhan Yang Maha Esa, berakhlak mulia, sehat, berilmu, cakap, kreatif, mandiri, dan menjadi warga negara yang demokratis serta bertanggung jawab.

Telah lama Indonesia menyelenggarakan pendidikan bahkan jauh sebelum kemerdekaan, namun tingkat ketercapaian tujuan pendidikan nasional sebagaimana manat undang-undang masih jauh dari harapan. Ketidaktercapaian tujuan ini terutama dari sisi iman, taqwa dan moral, bahkan mungkin semakin buruk. Dekadensi moral terjadi pada semua sektor. Perusakan lingkungan, penebangan hutan, polusi lingkungan (air, udara dan tanah) terjadi di manamana. Demikian juga penyalahgunaan pemakaian bahan-bahan kimia: formalin, borak, zat warna dan zat-zat aditif, konsumsi minuman keras dan narkoba di kalangan palajar yang memicu kejahatan-kejahatan lain, teror bom hingga peledakan bom bunuh diri makin marak terjadi.

Kenyataan ini menunjukkan telah terjadi missmatch dalam dunia pendidikan dan pembelajaran di Indonesia bahkan di seluruh dunia. Hal ini diduga sebagian besar dikarenakan pendidikan kita kurang mengembangkan potensi hati nurani (afektif), perkembangan kemampuan kognitif atau otaknya sangat maju tidak dikawal oleh perkembangan hati nurani maka akan berpotensi perusak. Dugaan ini sejalan dengan pendapat para ahli yang mengatakan bahwa kerusakan terjadi karena kurangnya penekanan pada masalah moral (Sauri, 2005), dan sistem pembelajaran di Indonesia masih bersifat parsial pada aspek kognitif semata (Djahiri, 1996). 
Pendidikan IPA merupakan bagian dari pendidikan nasional. Pendidikan IPA memiliki tujuan utama untuk menanamkan keyakinan terhadap Tuhan Yang Maha Esa berdasarkan keberadaan, keindahan dan keteraturan alam ciptaan-Nya (Depdiknas, 2008: 377). Tujuan utama ini merupakan sesuatu yang terus diperjuangkan melalui berbagai strategi. Salah satu alasannya, bagaimana tujuan yang sangat kental dengan istilah dan jiwa keagaman ini akan tercapai sementara sains yang diajarkan mulai TK sampai tingkat perguruan tinggi adalah sains warisan Barat yang jelas-jelas memisahkan atau menjauhkan dari agama. Sains di Indonesia mestinya merupakan sarana dalam mengabdi kepada Allah untuk mencapai kebahagiaan dunia dan akhirat.

Pada dasarnya tidak ada yang salah dengan sains Barat yang bersifat ilmiah, karena pada hakikatnya semuanya milik Allah. Sains yang mengkaji alam semesta merupakan milik Allah, tanda-tanda kekuasaan Allah (ayat kauniyah). Melalui ayat-ayat kauniyah semestinya dapat meningkatkan keimanan terhadap ayat-ayat qauliyah. Hal ini hanya akan tercapai seandainya : (1) motivasi atau niat untuk mempelajari sains karena Allah; (2) sains harus diberi makna/nilai/hikmah dari sudut pandang agama; (3) sains harus disyukuri, yaitu menggunakan sains berdasarkan pertimbangan dicintai dan tidaknya oleh Allah. Untuk hal ini maka harus ditanamkan nilai tauhid rububiyah dan ulubiyah dalam pembelajaran terutama melalui internalisasi pada materi ajar sains.

Dalam tulisan ini akan dicoba disajikan beberapa model internalisasi nilai tauhid dalam materi sains dengan harapan melalui materi sains akan membangkitkan potensi hati nurani atau afeksi bagi pembelajar yang akan bermuara pada peningkatan keimanan dan taqwa.

\section{PEMBAHASAN}

\section{Dialog Sains dengan Agama}

Peradaban Islam merupakan peradaban pertama yang mengintegrasikan ilmu pengetahuan dan agama secara terpadu. Sebagai dampak keterpaduan ilmu dan agama ini, peradaban Islam mencatat kebangkitan peradaban yang menghasilkan penemuan-penemuan ilmiah yang mengagumkan selama tujuh kurun pemerintahan Daulah Umayyah, Daulah Abbassiyyah, dan Daulah Fathimiyah.

Dalam agama Islam perpaduan antara agama dan sains bukan suatu hal yang asing, karena perintah Allah kepada Muhammad SAW sebagai utusan yang terakhir, yaitu perintah iqra atau membaca/menyelidiki (QS 96: 1-5), padahal pada saat itu kitab suci al-Qur'an belum ada, baru ayat tersebut yang diturunkan. Hal ini berarti, perintah membaca/menyelidiki juga termasuk membaca ciptaan Allah yang berada di alam semesta, yang sekarang dikenal dengan sains. Keyakinan ini disepakati oleh para ahli sains Muslim dari dulu sampai sekarang.

Pada dasarnya semua kitab-kitab suci yang diturunkan Allah kepada para utusannya (al-Qur'an yang diturunkan kepada Nabi Muhamad, Taurat kepada nabi Musa, Injil kepada Nabi Isa, Zabur kepada Nabi Daud) merupakan ayat- 
ayat qauliyah atau ayat yang tersurat dalam kitab suci. Sedangkan yang tersirat dalam alam semesta ciptaan-Nya merupakan ayat-ayat kauniyah. Kedua-duanya bermanfaat bagi manusia dan merupakan pasangan yang serasi dan saling menguatkan, tidak mungkin bertentangan karena berasal dari sumber yang sama yaitu Allah. Salah satu perbedaannya adalah ayat qauliyah kebenarannya mutlak. Sedangkan ayat kauniyyah kebenarannya relatif. Hal ini karena ayat qauliyah merupakan firman Allah langsung. Namun demikian di dalam ayat qauliyah (alQur'an) ternyata banyak dibicarakan tentang ayat kauniyyah. Bahkan menurut Syaik Jauhari Thanthawi, guru besar Universitas Kairo (Hartono, 2010: 76) mengungkapkan bahwa dalam al-Qur'an (ayat qauliyab) terdapat lebih dari 750 ayat kauniyah sedangkan ayat tentang fiqih hanya sekitar 150 ayat. Hal ini mengindikasikan betapa banyak pertalian antara ayat kauniyyah dengan ayat qauliyah. Betapa banyaknya al-Qur'an berekplanasi tentang alam semesta yang tidak lain merupakan kajian sains.

Jadi pada dasarnya, pada masa awal kebangkitan dunia sains diawali dengan hubungan yang mesra antara sains dan agama sedangkan pada masa kebangkitan Barat (setelah daulah Islam ditaklukkan oleh tentara Mongol dari Timur dan tentara Salib dari Barat) kebangkitan sains diawali dengan tidak harmonis hubungan sains dengan agama.

Pendidikan Sains pada masa sekarang di Indonesia merupakan warisan penjajahan Barat. Pendidikan yang memisahkan antara sains dengan agama yang menghasilkan kemajuan luar biasa dalam bidang sains dan teknologi, namun tidak berhasil membawa manusia kepada kebahagiaan sesungguhnya. Hal ini diindikasikan dengan terjadinya dekadensi moral.

Kesadaran akan dampak negatif dari sistem pendidikan yang memisahkan agama dari sains telah banyak disadari oleh berbagai kalangan Muslim. Sebagai respon terhadap hal ini bermunculanlah lembaga-lembaga pendidikan Islam yang berlabel sekolah terpadu, unggulan, plus, perguruan tinggi dan universitas Islam. Sebagian mahasiswa dan para pengajar Muslim telah melakukan beberapa penelitian mengenai integrasi sains dan agama baik dalam tataran menyiapkan materi ajar sains yang terintegrasi dengan agama, maupun upaya ke arah pembekalan kemampuan guru agar mampu melakukan integrasi (Hartono, 2011: 76 dan Rochman, 2010: 87). Semua ini menunjukkan kepedulian dan tanggungjawab sebagai masyarakat akademisi Muslim yang memiliki keyakinan pentingnya menyelaraskan atau memandu IPA dengan agama, walaupun semuanya masih dalam tataran mencari bentuk. Semoga Allah memberikan pahala atasnya. Pada dasarnya, semua ini merupakan suatu upaya untuk mengembalikan keterpaduan antara sains dan agama.

Agama yang bersumber dari wahyu akan berperan memberikan arahan, motivasi dan memastikan sains tersebut dapat berfungsi memberikan kebaikan, kemaslahatan, kesejahteraan lahir bathin umat manusia, bernilai ibadah, perwujudan sikap syukur dan sarana untuk meningkatkan iman dan taqwa dalam rangka mengabdi kepada Allah. Demikian juga menghadirkan sains pada agama 
dalam batas-batas tertentu dapat memberikan manfaat dalam meningkatkan keimanan seorang Muslim melalui pemahaman dan cara beragama yang lebih berkualitas, tidak terlalu dogmatis. Bila hal ini sudah membudaya pada dunia pendidikan sains maka akan menjadi jaminan tercapainya sumber kesejahteraan/keberkahan lahir dan bathin, dunia dan akhirat. Tujuan pendidikan nasional dan tujuan pembelajaran sains yang utama dapat diraih. untuk lebih jelasnya mengenai kedudukan sains dan agama dapat disajikan dalam gambar berikut ini:

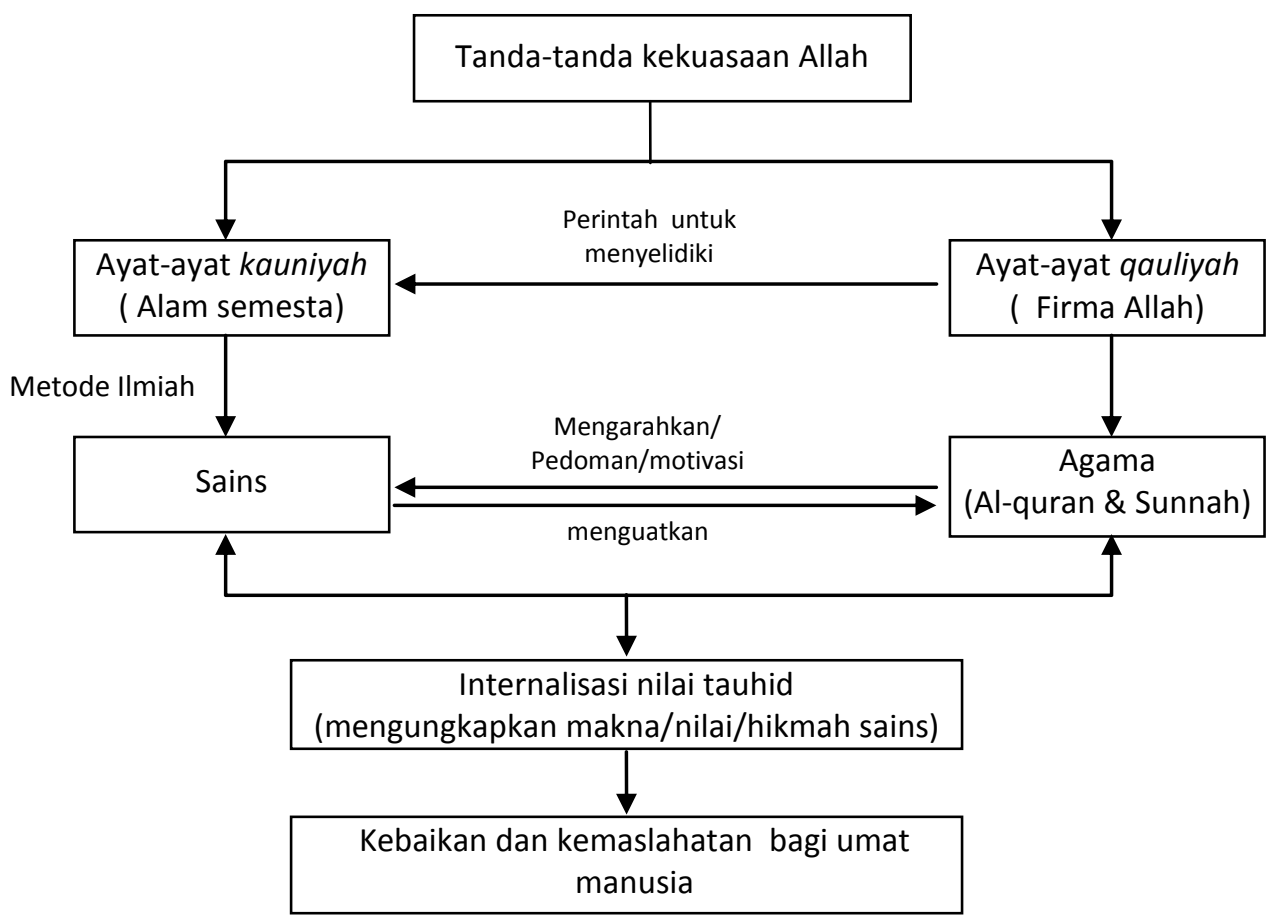

Gambar 1 : Kedudukan Dialogis antara Sains dan Agama

\section{Hakikat Tauhid}

Tauhid bermakna meng-Esakan Allah, baik dalam hal meyakini bahwa hanya Allah sebagai pencipta, pemelihara dan pemberi rizqi maupun dalam hal hanya Allah yang berhak disembah atau diibadahi, juga meyakini nama-nama yang baik dan sifat yang mulia bagi Allah (Departemen Agama, 2002; Amir, 1984; Firdaus, 1979; Harun, 2000). Lawannya adalah syirik yang berarti menyekutukan/membuat tandingan Allah. Tauhid merupakan hal yang paling penting dalam Agama Islam. Berikut ini dikutip beberapa dalil baik dari alQur'an maupun hadis yang dianggap terkait, yaitu:

a. "Dan sunggubnya Kami telab mengutus Rasul pada tiap-tiap umat untuk menyerukan sembablah Allah (saja), dan jaubilab Thaghut itu.” (QS. 16: 36) 
b. "Sesunggubnya Allah tidak akan mengampuni dosa syirik dan akan mengampuni dosa selain syirik bagi siapa saja yang dikehendaki-Nya." (QS. 4: 114).

c. "Dan tidaklah Kami menciptakan jin dan manusia melainkan banya untuk beribadabi/menyembah kepadaNya." (QS. 51: 56)

d. "Barang siapa meninggal sedangkan dia dalam keadaan bersaksi tidak ada Tuhan selain Allah dengan ikhlas dari hatinya maka sungguh Allah telah mengharamkan baginya neraka.” (H.R. Muslim).

Demikian juga ketika Rasulullah SAW sedang naik unta berdua bersama Muaz, ketika itu Rasulullah SAW bertanya tentang hak Allah atas hamba dan hak hamba atas Allah, selanjutnya Rasulullah SAW menyebutkan bahwa "Hak Allah atas hamba adalah bahwa hamba menyembab-Nya dan tidak. menyekutukan-Nya sedangkan hak hamba atas Allah, tidak diazab hamba yang tidak menyekutukan-Nya." ( H.R Bukhari).

Dalam hal pengajaran, disebutkan dalam hadis Anas bin Malik yang diriwayatkan di dalam Bukhari-Muslim dan selainnya. Rasulullah SAW ketika mengutus Muadz ke Yaman, beliau bersabda. "Hendaknya hal pertama yang engkau serukan kepada mereka adalah pesaksian babwa tidak ada Tuban yang berhak diibadahi kecuali Allah saja, maka jika mereka mentaatimu dalam hal itu... dan seterusnya sampai akhir hadis". (H.R Bukhari ).

Allah telah menegaskan bahwa untuk tauhid inilah para nabi diutus, Rasulallah telah mempraktikkannya dan sekaligus memerintahkan agar hendaklah yang pertama diseru adalah kalimat tauhid ini. Masih banyak lagi dalildalil al-Qur'an maupun sunah berkenanan dengan masalah tauhid yang menunjukkan betapa tauhid merupakan hal yang paling penting dan merupakan inti dari ajaran Islam. Tidaklah bermanfaat secara akhirat amal apapun selagi pelakunya syirik atau tauhidnya rusak. Bahkan tidak berlebihan jika dikatakan bahwa hanya dengan tauhid yang baik maka segala hal yang lainnya akan baik dan tidak sebaliknya. Tidak mengherankan kalau Rasulallah berdakwah selama 13 tahun di Mekah hanya menyeru kepada tauhid, demikian juga Nabi Nuh hingga 950 tahun beliau mendakwahkan tauhid walaupun hasilnya hanya segelintir orang saja yang beriman.

Kita mengenal bahwa tauhid terbagi tiga. Pertama, Tauhid Rububiyah, yaitu tauhid mengesakan Allah dengan perbuatan-Nya, seperti keyakinan hanya Allah yang menciptakan dan memelihara langit dan bumi, yang memberi rizqi, yang menghidupkan dan mematikan. (QS. 10: 31 dan QS. 40: 84-89 ). Tauhid inilah yang telah diyakini oleh orang-orang musyrik Quraisy. Kedua, Tauhid Uluhiyah, yaitu mengesakan Allah dengan perbuatan-perbuatan ibadah, seperti shalat, nazar, sedekah dan lain sebagainya. Untuk tujuan tauhid ulubiyah ini para Rasul diutus dan kitab-kitab diturunkan (QS. 47: 19). Ketiga, Tauhid asma' wa sifat, yaitu tauhid yang menetapkan apa yang telah ditetapkan oleh Allah dan Rasul-Nya berupa nama-nama yang baik, sifat yang mulia bagi Allah tanpa tabrif 
Ayi Darmana

(penyelewengan), ta'thil (penafian), takyif (bertanya bagaimana) dan tamtsil (penyerupaan).

\section{Tauhid dan Sains}

Allah menjadikan manusia sebagai khalifah di planet bumi ini (QS. 2: 31). Selanjutnya Allah menundukan langit, bumi, daratan dan lautan beserta apa yang ada di dalamnya untuk manusia (QS. 14: 32-33; QS. 16: 12-14; QS. 22: 65; QS. 31: 20; QS. 45: 12; QS. 10:101).

Manusia dianugrahi pendengaran, penglihatan dan hati nurani (QS. 16: 78). Manusia pun dibedakan dengan makhluk lain dengan diberi akal dan fikir, diperintahkan untuk mempelajari dan meneliti agar mampu menguasai, mengendalikan, dan mengambil memanfaat dari alam ini secara penuh tanggungjawab, yaitu dengan menggunakannya untuk kemaslahatan, kesejahteraan lahir dan bathin seluruh umat manusia. Ini semua merupakan anugerah Allah yang wajib disyukuri. Betapa Allah telah meninggikan dan memuliakan derajat manusia jauh dibanding makhluk-makhluk lain. Semua ini merupakan sarana untuk mencari ridlo Allah dan beribadah kepada Allah. Tauhid memberikan spirit kepada manusia untuk menguasai dan menundukkan alam, bukan sebaliknya, manusia tunduk kepada alam atau bahkan menyembah alam (syirik). Kemampuan menundukkan, menguasai dan memanfaatkan sumber daya alam mestinya menjadikan manusia lebih rajin beribadah kepada Allah dan semakin taat kepada-Nya.

Ilmu pengetahuan alam (IPA) atau sains merupakan salah satu disiplin ilmu yang objek kajiannya alam (makhluk) yang dapat diobservasi. Ada dua hal yang berkaitan dengan sains yang tidak terpisahkan, yaitu sains sebagai produk dan sains sebagai proses. Sains sebagai produk yaitu pengetahuan sains berupa fakta, konsep, prinsip, hukum, dan teori sebagai hasil temuan para ilmuwan. sedangkan sains sebagai proses lebih menjelaskan tentang bagaimana sains itu diperoleh atau sains dikembangkan melalui penyelidikan.

Gejala-gejala alam itu diselidiki menggunakan alat ukur yang salah satunya pendengaran dan penglihatan untuk mengumpulkan data. Data yang dihasilkan dianalisis sehingga ditemukan pola-pola atau keteraturan-keteraturan. Disusun hipotesis, kemudian dilakukan lagi pengamatan untuk mengumpulkan data, dilakukan interpretasi hingga hipotesis tersebut didukung atau tidak. Sehingga setelah mengalami proses pengujian secara ilmiah diperoleh ilmu pengetahuan alam. Tahap-tahap ini dilakukan secara sistematis atau lebih dikenal dengan metode ilmiah

Bila diperhatikan proses dihasilkannya sains, maka jelas bahwa sains sangat menekankan pada pengamatan/observasi serta analisis dan interpretasi secara logis dan sistematis. Inilah ciri penyelidikan atau penelitian. Allah beribu-ribu tahun yang lalu telah memerintahkan dalam banyak ayat al-Qur'an, untuk menyelidiki apa yang di langit dan di bumi, diantaranya al-Qur'an Surat Yunus ayat 101 . Kemudian di ujung ayat tersebut seolah-olah Allah menyayangkan 
bahwa kenapa menyelidiki apa yang ada di langit dan bumi tidak membawa manusia beriman (menyembah Allah). Karena itu, semestinya dengan mempelajari sains, kadar keimanan dan ketaqwaan seorang hamba kepada Allah semakin meningkat.

Pada ayat lain, Allah berfirman bahwa telah menjadikan bagi manusia pendengaran, penglihatan dan hati nurani agar manusia bersyukur (QS. 16: 78). Ayat ini sangat bersesuaian dengan pembicaraan di atas. Bukankah pendengaran dan penglihatan itu sebagai alat untuk memperoleh pengetahuan yang melalui metode ilmiah akan menghasilkan ilmu pengetahuan. Dari sini kita mengetahui bahwa manusia tidak menjadi baik, tidak beriman dan tidak bersyukur karena belum memfungsikan atau belum mengembangkan satu anugrah lagi yaitu potensi hati nurani. Hati nurani ini yang akan menjadi penentu apakah ilmu pengetahuan yang diperoleh akan menjadi kebaikan bagi umat manusia atau bahkan menjadi keburukan bagi umat manusia. Agar ilmu pengetahuan ini menjadi kebaikan atau bermanfaat (istilah agama barakah) maka mesti memfungsikan hati nurani. Hati nurani yang terbimbing dengan hidayah agama.

Internalisasi nilai tauhid dalam materi sains merupakan upaya untuk mengembangkan potensi hati nurani, sehingga akan mengarahkan kepada kesadaran bahwa sains terutama hukum-hukum atau fakta-fakta, merupakan ketetapan dan kekuasaan Allah Yang Maha Kuasa, yang diciptakan dan dianugerahkan untuk kemaslahatan makhluk-Nya. Kesadaran ini akan mendorong dan menjadi motivasi untuk menggunakan ilmu pengetahuan pada kebaikan dan kemaslahatan umat manusia serta pada hal-hal yang diridloi oleh Allah Yang Maha Esa.

Keberhasilan menguasai alam tetapi tidak mengantarkan kepada dihasilkannya manusia yang beriman menunjukkan adanya kekurangan. Salah satu kekurangan tersebut adalah karena potensi hati nurani yang belum dikembangkan, sehingga motivasi dalam melakukan penelitian bahkan pembelajaran di kelas yang sama sekali kering dari spiritual keagamaan. Sains telah memutuskan diri berhubungan dengan aspek spiritual keagamaan. Sains memandang objek alam ini sebagai suatu yang terisolasi, yaitu tidak ada hubungannya dengan aspek spiritual. Sains tidak ada hubungannya dengan makna dan hikmah Allah menciptakan alam ini. Sehingga tidak jarang setelah menguasai sains maka yang terjadi adalah kesombongan atau keangkuhan, hingga menjadi pembangkang, anti Tuhan atau bahkan menjadi atheis. Hal ini karena dengan kaidah-kaidah ilmiahnya, manusia merasa telah mendapat pemahaman yang sempurna terhadap alam ini. Padahal klaim kesempurnaan pengetahuan manusia adalah sebatas pemahaman dan penguasaan serta pengendalian alam yang serba terbatas, sementara hakikat semua ini untuk apa, menjadi buta. Bahkan mungkin mereka berkeyakinan bahwa alam ini terjadi begitu saja, dan mencukupkan untuk berterimakasih kepada alam, yang tentu ini dapat menghantarkan kepada anti tauhid atau kesyirikan. 
Memasukkan aspek spiritual keagamaan dalam materi sains tidak akan mengurangi kadar keilmiahannya. Keilmiahan merujuk pada bagaimana cara memperoleh sains, sedangkan aspek spiritual merujuk pada motivasi dalam melakukan proses ilmiah dan arahan terhadap penggunaan atau tujuan setelah sains itu tercapai. Jadi, pada dasarnya, antara sains dan aspek spiritual yang akan mengarahkan kepada keimanan, ketaqwaan dan rasa syukur dapat saling menguatkan dan melengkapi yang pada akhirnya akan bermuara pada penguatan tauhid. Sebagaimana Allah jelaskan mengenai ciri-ciri ulil albab (QS. 3 : 190191). Untuk lebih jelasnya disajikan dalam gambarkan sebagai berikut:

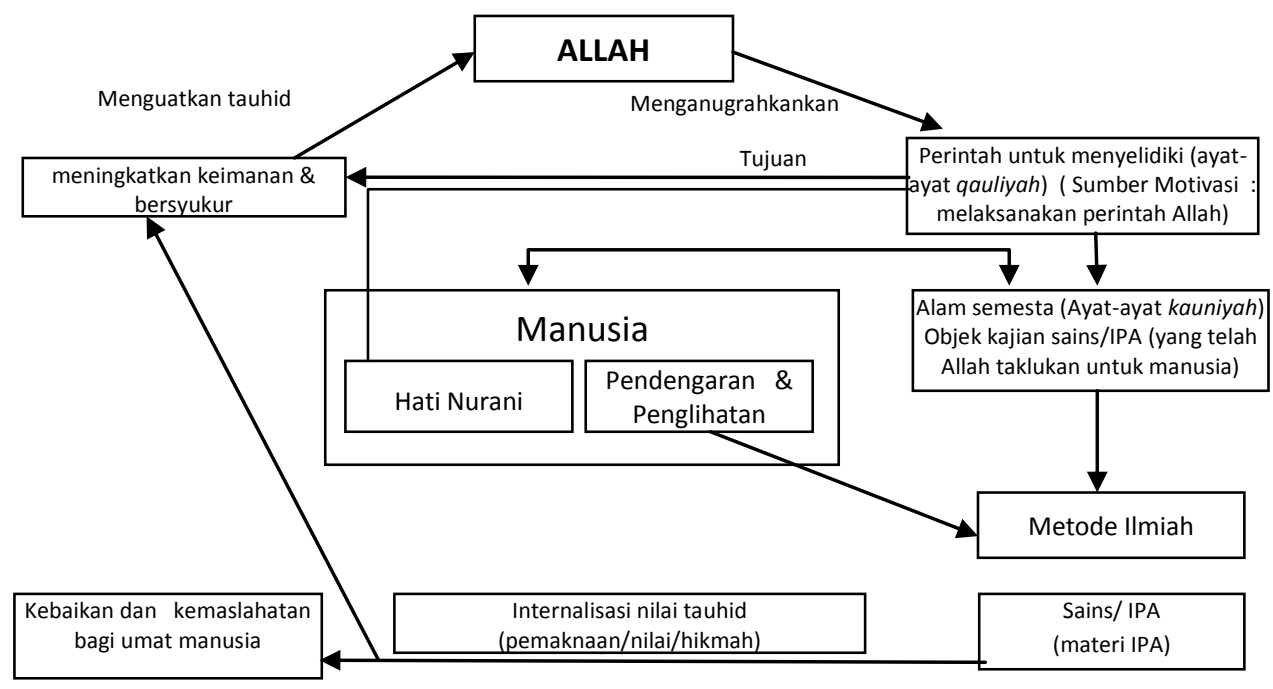

Gambar 2 : Tujuan dan Motivasi Melakukan Penyelidikan serta Pemaknaan

\section{Internalisasi Nilai Tauhid dalam Pembelajaran Sains}

Dasar pemikiran adanya integrasi agama dan sains, hakikat tauhid, tauhid dan sains. Secara etimologis, internalisasi menunjukkan suatu proses. Dalam kaidah Bahasa Indonesia akhiran "isasi” mempunyai arti proses, sehingga internalisasi dapat didefinisikan sebagai suatu proses (Ardiansyah, 2011: 40). Dalam Kamus Besar Bahasa Indonesia, internalisasi diartikan sebagai penghayatan, pendalaman, penguasaan secara mendalam yang berlangsung melalui binaan, bimbingan dan sebagainya (Kamus Besar Bahasa Indonesia, 1989). Sedangkan dalam kamus Oxford. "internal" berarti "of or in the inside" ( Hornby et all, 1986) yang berarti bagian dalam.

Menurut Departemen P \& K (2004) internalisasi merupakan suatu proses yang dialami seseorang sepanjang hidupnya, dalam hal menerima dan menjadikan bagian milik dirinya, berbagai sikap, cara mengungkapkan perasaan atau emosi, pemenuhan hasrat, keinginan, nafsu atau keyakinan, norma-norma 
dan nilai-nilai sebagaimana yang dimiliki oleh individu-individu lain dalam kelompoknya.

Proses terjadinya internalisasi dapat melalui berbagai tahap atau metode. Beberapa pakar menyebutkan bahwa internalisasi merupakan potensi dunia afektif yang terjadi setelah melalui tahap penerimaan, pemahaman, merespon, dan menilai. Internalisasi nilai, sebagaimana mengajarkan nilai dapat dilakukan dengan mengikuti tahap-tahap: orientasi/informasi, pemberian contoh dan non contoh, latihan/pembiasaan atau drill, refleksi atau umpan balik dan tindak lanjut serta penguatan.

Menurut Muhaimin (Ardiansyah, 2011: 57), ada tiga tahap terjadinya internalisasi yaitu: (1) tahap transformasi nilai, tahap ini merupakan suatu proses yang dilakukan oleh pendidik dalam menginformasikan nilai-nilai yang baik dan kurang baik. Pada tahap ini hanya terjadi komunikasi verbal antara pendidik dan peserta didik atau anak asuh; (2) tahap transaksi nilai, suatu tahap pendidikan nilai dengan jalan melakukan komunikasi dua arah, atau interaksi antara peserta didik dengan pendidik yang bersifat interaksi timbal-balik; (3) tahap transinternalisasi, tahap ini jauh lebih mendalam dari tahap transaksi. Pada tahap ini bukan hanya dilakukan dengan komunikasi verbal tapi juga sikap mental dan kepribadian. Jadi, pada tahap ini komunikasi kepribadian yang berperan secara aktif.

Ada beberapa metode atau strategi internalisasi cara yang dapat dilakukan. Murdiono (2010) mengungkapkan, bahwa strategi internalisasi nilai-nilai religius dalam pembelajaran meliputi keteladanan, masalah aktual di masyarakat, penanaman nilai-nilai edukatif secara kontekstual, dan penguatan nilai moral. Hal senada diungkapkan oleh Simon, Howe, dan Kirschenbaum (Wahab, 2007), bahwa dalam internalisasi nilai-nilai moral dapat dilakukan dengan empat pendekatan, yaitu pendekatan penanaman moral, pendekatan transmisi nilai bebas, pendekatan teladan, dan pendekatan klarifikasi nilai. Sedangkan menurut Fu'ad (dalam Jamaluddin, 2010) penanaman nilai tauhid/akidah dapat dilakukan dengan berbagai cara, diantaranya: analogi, hikmah, melalui kisah, dan dialog melalui pendekatan logika.

Berdasarkan beberapa rujukan di atas maka dapat disimpulkan bahwa internalisasi adalah suatu proses penanaman nilai-nilai secara mendalam sehingga membentuk kepribadian, menjadi falsafah, keyakinan yang kuat dan menjadi landasan untuk cara pandang, berfikir, bersikap dan bertindak. Internalisasi terjadi melalui berbagai tahap dan dapat dilakukan dengan berbagai pendekatan atau cara.

Internalisasi nilai tauhid dalam materi sains, diharapkan akan timbul keyakinan tentang segala sesuatu diciptakan Allah dan tidak sia-sia, adanya keyakinan tentang ketundukkan, karakteristik dan keteraturan dari benda-benda yang Allah ciptakan (sunatullah), sehingga manusia dapat mempelajarinya. Semua ini akan memungkinkan tumbuhnya sikap positif, takjub/kagum akan kebesaran, kekuasaan dan kasih sayang Allah, menjadi motivasi untuk 
bersyukur, meningkatkan keimanan dan ketaqwaan kepada Tuhan yang Maha Esa sebagaimana yang ditetapkan dalam tujuan pendidikan nasional.

Internalisasi nilai tauhid dalam materi sains berarti menanamkan/ memasukkan nilai tauhid dalam materi sains, sehingga sains yang tadinya hanya bersifat ilmiah yang hanya dapat mengembangkan potensi kognitif menjadi sains yang dapat juga mengembangkan potensi afektif (hati nurani). Hal ini dapat dilakukan dengan mengungkapkan nilai/hikmah/makna atau pesan moral dari materi sain tersebut berdasarkan sudut pandang agama. Sebagai contoh, ketika menjelaskan topik air, tidak cukup menjelaskan bahwa air merupakan senyawa kimia dengan rumus molekul $\mathrm{H}_{2} \mathrm{O}$, melainkan dijelaskan pula bahwa air adalah anugerah yang diberikan oleh Allah kepada manusia untuk dimanfaatkan sebagai sumber kehidupan bagi sekalian makhluk-Nya baik manusia, tumbuhan dan hewan serta dijelaskan pula tentang proses pengelolaan dan pengolahannya. Penyajian semacam ini akan berdampak sangat positif pada hasil belajar siswa sehingga siswa memiliki keinginan untuk melihat air sebagai sumber ekonomi (usaha) bahkan memungkinkan siswa akan menghargai air dalam arti memelihara dan menjaga kelestariannya. Sikap ini cukup bagus untuk mengingatkan peserta didik tentang siapa yang menganugerahkan air tersebut. Dengan demikian diharapkan bahwa manusia melalui pendidikan yang terpadu ini mendapatkan kebaikan di dunia dan akhirat sesuai dengan tujuan luhur pendidikan nasional. Kuncinya adalah materi sains tidak boleh dilepaskan dari agama.

Menghadirkan sudut pandang agama terhadap topik air melalui internalisasi nilai tauhid, akan menghasilkan siswa yang memiliki sikap-sikap positif di antaranya tidak sombong karena semua sama diciptakan dari air, takjub akan kebesaran Allah, merasa diberi nikmat yang banyak, yang akhirnya malu untuk mendurhakai Allah. Dari sikap ini akan tumbuh sikap bersyukur dan hasrat untuk menggunakan pengetahuannya dengan pertimbangan mencari ridlo Allah, berhasrat untuk melakukan perintah yang lainnya, bahkan selanjutnya diharapkan akan meningkatkan keimanan dan ketaqwaan kepada Allah sebagai pencipta, pemelihara, pengasih dan penyayang.

Dalam bagian ini akan disajikan model internalisasi nilai tauhid dalam materi sains berupa fakta, konsep atau hukum-hukum. Selanjutnya, akan dibahas pula contoh dalam menerapkannya dengan memilih topik siklus air dan anomali air. Sebelumnya akan disajikan beberapa kaidah, batasan yang melandasi kerangka fikir penulis dalam menyajikan model internalisasi nilai tauhid tersebut. Hal ini dimaksudkan untuk menghindari kesan memberikan interpretasi yang sembarangan atau berlebih, sehingga jatuh kepada kemadaratan yang lebih besar.

Batasan-batasan tersebut meliputi :

a. Tidak memaksakan, sederhana, maksudnya tidak perlu dicari-cari kaitannya kalau memang secara substansinya tidak berhubungan. Internalisasi nilai tauhid hanya terbatas untuk tujuan mengarahkan yang dapat dilakukan di awal atau di akhir dari materi sains tanpa melakukan integrasi. 
b. Tidak ada perintah dalam agama untuk mengomentari materi sains, agama fungsinya bukan menjelaskan sains, tetapi jika dalam agama disebutkan tentang materi sains maka agama menjadi hakim, rujukan dan standar. Hal ini berarti kalau seandainya temuan sains tidak cocok dengan agama maka pasti karena keterbatasan sains, sains yang keliru (dengan syarat syariat itu benar telah sahih dari sisi periwayatan, isi bahkan dari bagaimana harus dipahaminya)

c. Dengan sains pemahaman terhadap beberapa bagian agama akan makin baik, makin kuat, karena banyak yang tersurat dapat dijelaskan dengan sains, banyak yang tidak detail atau hanya secara rinci maka sains merincinya, sehingga bagi saintis tingkat dogmatis agama agak berkurang, dengan catatan bahwa sains sifatnya untuk memahami dalam batas-batas tertentu yang tentu tidak dapat memahami dunia yang bukan empiris, dan juga ketidak berhasilan sains untuk memberi pemahaman terhadap syariat bukan berarti kita boleh menolaknya.

d. Kenyataan yang diketahui bahwa ada dua kemungkinan untuk materi sains: Pertama, materi sains tersebut diisyaratkan dalam agama baik secara ekplisit (jelas, melalui penukilan dalil sehingga umumnya orang mengetahui bahwa hal tersebut ada dalam agama walaupun tidak dipahaminya) ataupun secara implisit (samar, mungkin hanya diketahui dan dipahami oleh ulama). Hal ini sebagaimana yang telah diungkapkan oleh Syaik Thanthawi Jauhari, guru besar Universitas kairo (Hartono, 2010: 76) yang mengungkapkan bahwa dalam al-Qur'an (ayat qauliyah) terdapat lebih dari 750 ayat kauniyah. Proses penciptaan dan kejadian manusia, terjadinya hujan, alam semesta, langit, bumi, gunung, binatang, tumbuh-tumbuhan merupakan sebagian contoh yang dikaji dalam sains dan dinukil dalam al-Qur'an. Sedangkan proses mengenai bagaimana tumbuhan ditanam agar pertumbuhannya baik, foto sintesis, sifat-sifat material, fenomena anomali air, fungsi darah, dan zat-zat makanan adalah merupakan beberapa contoh yang tidak dinukil dalam al-Qur'an atau mungkin hanya disebutkan secara isyarat (implisit). Kedua, materi sains yang tidak diketahui keterkaitannya baik secara ekplisit maupun implisit dalam al-Qur'an.

e. Pada dasarnya terhadap semua materi sains baik yang dinukil maupun tidak dalam ayat qauliyah dapat dilakukan internalisasi nilai tauhid. Hal ini didasari keyakinan bahwa Allahlah yang telah menciptakan semuanya dengan tidak sia-sia ( QS. 3: 191 dan QS. 59: 24). Perbedaan kedudukan materi sains ini hanya akan membawa konsekwensi kepada perbedaan dalam menginternalisasi. Materi sains yang sama sekali tidak terkait dalam al-Qur'an dan hadis, internalisasi nilai tauhidnya lebih baik dilakukan pada akhir penyajian materi sains dengan penekanan pada bagaimana menyadarkan siswa bahwa hal tersebut merupakan 
anugerah Allah yang wajib disyukuri dengan cara menggunakan pengetahuan tersebut dalam perkara yang diridloi-Nya.

f. Materi sains yang terkait dalam agama (al-Qur'an/hadis), internalisasi dapat dilakukan sejak awal dengan terlebih dahulu siswa ditugaskan untuk mencari dalil al-Qur'an/hadis yang berkenaan dengan topik sains. Upaya ini dimaksudkan terutama untuk menanamkan budaya membaca al-Qur'an/hadis dan menjadikannya sebagai dasar untuk mempelajari sains baik dalam hal membangun motivasi, atau pemahaman tentang batasan-batasan sebagai tolok ukur sains(supaya sains tidak menyalahi al-Qur'an/hadis). Dalam hal ini perlu ditekankan pada siswa bahwa al-Qur'an/hadis berfungsi sebagai pedoman/tolok ukur sains. Sebagai pedoman tentu bersifat umum sedangkan rinciannya terdapat dalam sains itu sendiri. Hal ini mudah dipahami, sebagaimana hadis Rasullah SAW yang salah satunya berfungsi untuk merinci/menjelaskan al-Qur'an dalam hal yang berkenaan dengan peribadatan. Hal yang sama, sains harus memiliki fungsi merinci/ menjelaskan al-Qur'an/hadis dalam batas-batas kemampuan sains yang berhubungan dengan alam. Sehingga meningkatkan pemahaman terhadap agama dengan tidak dogmatis. Hal ini sangat perlu dijelaskan oleh guru untuk menghindari timbulnya kesalahpahaman sikap siswa yang lebih menganggap bahwa sains lebih unggul dari agama, karena sains lebih dapat memberi penjelasan yang lebih komprehensip. Sikap ini akan memicu timbulnya keyakinan bahwa sains segala-galanya, mencukupkan dengan sains dan tidak memerlukan agama. Tahap selanjutnya, internalisasi dilakukan melalui integrasi sains dengan agama. Pada integrasi, topik yang sama ditinjau dari perspektif agama dan sains yang tujuannya selain mendapatkan pemahaman yang lebih baik juga untuk mengoptimalkan potensi afektif (hati nurani). Sebagai contoh "proses terjadinya hujan", Allah telah menjelaskannya dalam al-Qur'an secara jelas, sementara dalam sains pun merupakan salah satu materinya. Dalam hal ini dapat dilakukan melaui integrasi.

Berikut ini disajikan contoh dalam menerapkan model internalisasi nilai tauhid dalam materi sains. Materi sains yang dipilih adalah dua topik, yaitu topik terjadinya hujan dan topik anomali air (air dalam keadaan wujud padat biasa disebut es memiliki volume yang lebih besar dari volume air pada massa yang sama).

Topik terjadinya hujan merupakan topik sains yang dinukil di dalam ayat al-Qur'an Surat an-Nur ayat 43, sedangkan topik anomali air tidak diketahui penukilannya dalam al-Qur'an kecuali dengan dalil yang umum, seperti yang tercantum dalam Surat Ali Imran ayat 191 yang menyatakan bahwa "....tidak ada ciptaan Allab sia-sia", demikian juga dalam Surat al-Hasyr ayat 24 yang mengatakan bahwa "...Dia-lah Allah yang menciptakan, yang mengadakan." 
Untuk topik "turun hujan", tahap persiapan pembelajaran dapat dimulai dengan penugasan agar mereka mencari/menelaah ayat dalam al-Qur'an, penugasan ini dapat dilakukan satu minggu sebelumnya atau pada saat memulai pelajaran, salah satu tujuannya untuk pembudayaan membaca al-Qur'an. Sedangkan untuk topik "anomali air" tidak perlu diberi tugas untuk mencari ayat al-Qur'an yang bersesuaian. Kedua hal ini tidak disajikan dalam gambar 3 di atas, mengingat yang disajikan hanya terbatas pada internalisasi pada materi bukan pada keseluruhan pembelajaran sains. Namun demikian, internalisasi di penghujung pembahasan materi sains termasuk sukar dihindarkan, dengan pertimbangan kalau ini tidak dilakukan maka berarti hanya melakukan internalisasi pada saat pembahasan topik materi sains yang dinukil dalam alQur'an (integrasi). Hal ini akan kurang operasional mengingat hanya sedikit yang dinukil secara ekplisit dalam ayat al-Qur'an.

Berdasarkan batasan dan kerangka fikir disaiikan model internalisasi nilai tauhid sebagai berikut:

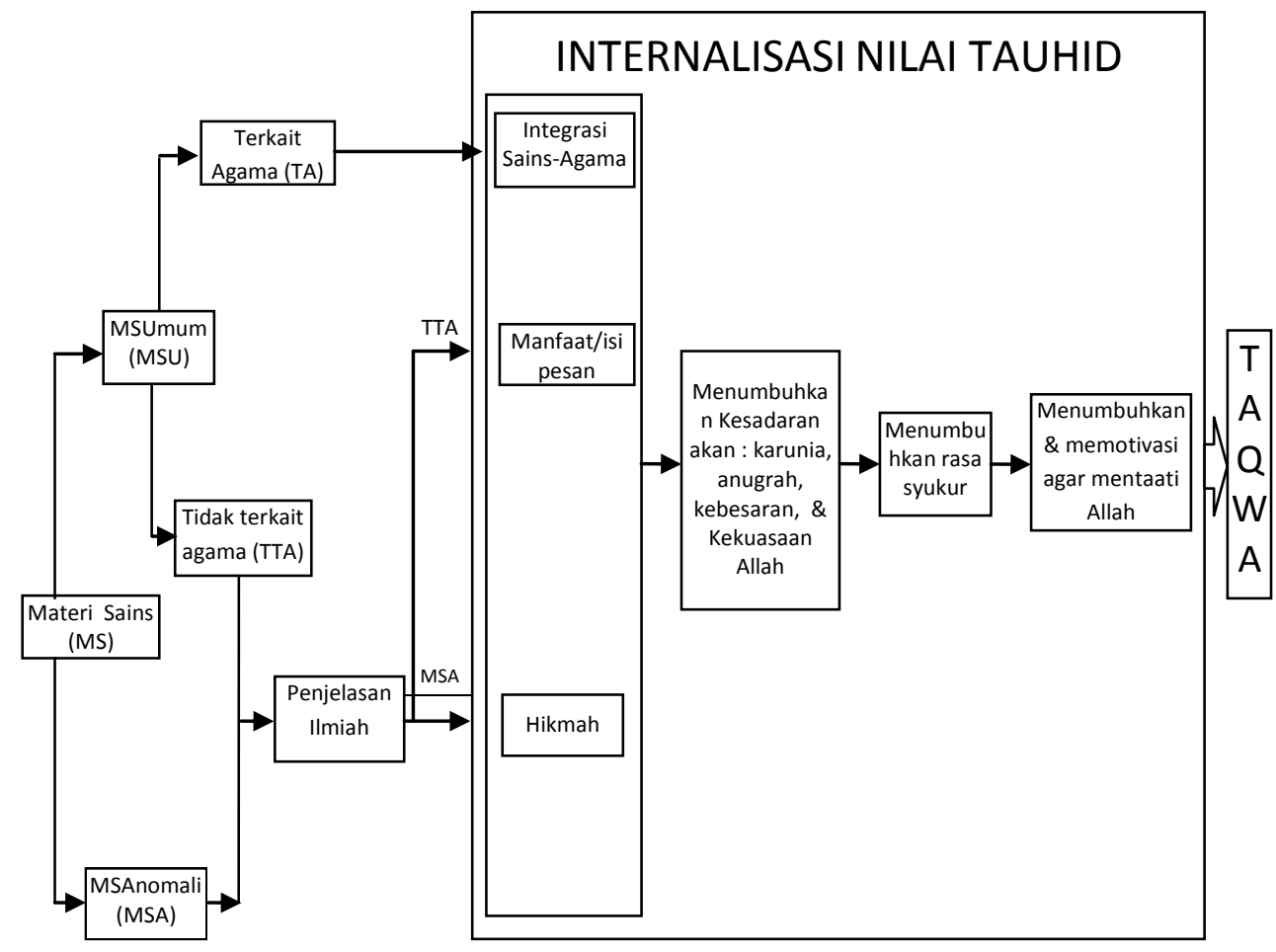

Gambar 3 : Internalisasi Nilai Tauhid dalam Pembelajaran Sains

Berikut ini akan disajikan masing-masing model internalisasi nilai tauhid pada materi sains:

a. Topik turun hujan 
Berdasarkan gambar 3 di atas topik ini merupakan topik umum yang terkait dengan agama (dinukil dalam Surat an-Nur ayat 43). Internalisasi nilai tauhid dilakukan melalui integrasi sebagai berikut:

Tidakekah kamu melihat bahwa Allah mengarak awan, kemudian mengumpulkan antara (bagian-bagian) nya, kemudian menjadikannya bertindih-tindih, maka kelihatanlah olebmu bujan keluar dari celab-celabnya ...(QS. 24 : 43).

Sedangkan dalam sains, terjadinya hujan secara ringkas dapat dijelaskan melalui siklus air, sebagai berikut:

Air yang ada di permukaan bumi (air laut, danau, sungai) menguap naik ke atas (ke udara), di udara molekul air bergerak dan berkondensasi dengan molekul air yang lain, sehingga turun bujan.

Perbedaan dari prespektif agama dan sains tentang topik turun hujan ini, hanya dalam sains disebutkan bahwa uap air itu berasal dari permukaan bumi, selebihnya itu hanya perbedaan istilah tapi maknanya sama misalnya: "mengarak" identik dengan "bergerak". "mengumpulkan dan bertindih-tindih" identik dengan "kondensasi". Dengan demikian dapat dikatakan tidak ada perbedaan perspektif. Namun sains memiliki penjelasan yang lebih rinci yang menjawab pertanyaan apa kenapa dan bagaimana hal itu terjadi.

Uap air adalah air dalam bentuk molekul air yang terpisah jauh dari molekul air yang lainnya, atau molekul air yang karena panas terlepas dari molekul cairnya. Uap air naik ke udara karena lebih ringan, dan karena ada perbedaan tekanan, udara bergerak (angin) menuju tekanan yang rendah, makin lama uap air makin ke atas sampai suhunya berkurang, bergeraknya makin lambat, makin berdekatan dengan molekul uap air yang lain dan saling bergabung membentuk awan (terjadi kondensasi) jika kondensasi air terjadi dari sejumlah molekul air yang memungkinkan tetes air terbentuk maka dengan gravitasi air akan turun berupa air hujan ke bumi. ( dengan asumsi 1 tetes air = $0,05 \mathrm{~g}$, massa jenis air $1 \mathrm{~g} / \mathrm{ml}, 18 \mathrm{~g}$ air mengandung $=6,02 \times 10^{23}$ molekul air. maka 1 tetes air mengandung sekitar $17 \times 10^{23}$ molekul air).

Dari kedua tinjauan ini terlihat bahwa terjadinya hujan menurut sains lebih lengkap dan dapat lebih merinci serta menjelaskan apa yang Allah firmankan dalam ayat di atas tadi. Dalam hal ini, sains dapat meningkatkan pemahaman seorang Muslim terhadap ayat al-Qur'an. Bagaimana sumbangan perspektif al-Qur'an terhadap sains? Al-Qur'an hendak menjelaskan bahwa yang menurunkan, mengatur dan menetapkan air hujan adalah Allah. Namun manusia dapat mengetahui secara sunatullab mengenai sebab-sebabnya. Karena itu, manusia dalam batas tertentu dapat mengupayakan mempercepat turunnya hujan melalui hujan buatan (bukan menurunkan/menciptakan hujan) yaitu dengan prinsip mengupayakan agar mudah terjadi kondensasi. Hujan buatan dilakukan dengan menaburkan garam pada ketinggian tertentu (garam memiliki sifat menyerap air, sehingga dapat mempercepat terjadinya kondensasi). Perlu ditekankan walaupun secara teori manusia dapat mengupayakan hujan buatan 
tetapi kenyataannya sangat tidak efesien terutama terlalu besar biaya operasinalnya. Hal ini akan menyadarkan betapa Allah telah menganugrahkan air hujan ini dengan gratis. Allah mutlak memberikannya kepada semua mahluknya terutama manusia. Ini merupakan penanaman tauhid rububiyah. Hal ini perlu ditegaskan dalam rangka menumbuhkan sikap bersyukur pada siswa.

Selanjutnya, jika memungkinkan dari segi waktu, maka materi dapat dilanjutkan dengan menjelaskan peran air hujan. Bukankah Allah telah berfirman dalam banyak ayat yang menyebutkan bahwa Allah telah menurunkan air hujan dari langit lalu dengan air menjadi sumber kehidupan bagi manusia. Perhatikan firman Allah berikut. "Dia menurunkan air (bujan) dari langit, lalu Dia menghasilkan dengan bujan itu segala buab-buahan sebagai reqeki untukmu; karena itu janganlah kamu mengadakan sekutu-sekutu bagi Allah, padahal kamu mengetabui (QS.2 :22). Dan Kami turunkan air bujan dari langit, lalu Kami tumbubkan padanya segala macam tumbubtumbuhan yang baik." (QS.31: 10)

Jika semua pembelajaran yang dialami siswa dari mulai TK sampai perguruan tinggi dengan model seperti ini yaitu melibatkan agama untuk mengembangkan hati nurani maka sangat mungkin diperoleh manusia utuh sebagaimana tujuan pendidikan nasional.

Mengenai metode dan pendekatan yang biasa dilakukan dalam pembelajaran yang telah teruji dapat mengembangkan kemampuan kognitifnya, maka tetap dapat dilakukan dalam pembelajarn yang melibatkan internalisasi nilai tauhid seperti ini.

b. Anomali Air

Dalam gambar model internalisasi, untuk materi sains yang termasuk anomali maka internalisasi dilakukan dengan mengungkapkan hikmahnya. Anomali berarti penyimpangan, Umumnya benda kalau dipadatkan maka volumenya menjadi lebih kecil. Hal ini tidak berlaku bagi air, jika air dipadatkan atau diubah dari air wujud cair ke air wujud padat (es) maka volumenya berkurang. Karena massanya sama maka masa jenis es menjadi lebih kecil, sehingga es mengapung dalam air.

Adanya fakta bahwa es (air pada suhu rendah/air fasa padat) mengapung dalam air adalah diketahui oleh kebanyakan orang, berikut faktanya: Jika air pada suhu kamar $\left(25^{\circ} \mathrm{C}\right)$ diturunkan suhunya perlahan maka molekul-molekul air saling mendekat, sehingga volume air mengecil. Keadaan ini berlangsung hingga suhu $4 \circ$ C. Mulai pada suhu ini penurunan suhu berikutnya menyebabkan volumenya naik hingga terbentuk es. Penjelasannya hal ini dikarenakan pada suhu rendah molekul es menjadi kaku, sehingga molekul air menjadi sukar saling mengatur diri, akibatnya volume menjadi berkembang.

Penjelasan ini tidak dapat memberikan kesan apa-apa selain kesan kognitif. Tetapi kalau kita coba jelaskan dengan pendekatan berwawasan agama, yaitu sebagai barikut : bahwa fakta terjadinya anomali air ini mengandung hikmah yang sangat besar. Kalau berlaku hal yang umum pada air yaitu jika dipadatkan atau 
dibuat es volumenya mengecil yang berarti masa jenisnya membesar maka akibatnya es akan tenggelam dalam air. Mari kita fikir apa yang terjadi di daerah kutub, yang tidak pernah ada matahari sehingga semua air permukaan menjadi es. Bagaimana jadinya kalau es itu tenggelam di dalam air? Bukankah es itu akan menutupi dasar laut? Semua makhluk hidup yang mengambil makanan dari dasar laut akan mati. Bukankah akan terjadi luapan permukaan air yang akan menimbulkan banjir besar jika suhu bumi naik? Cara pembahasan seperti ini yang harus diungkapkan pada anak didik kita, sehingga akan menumbuhkan perasaan kekaguman akan kekuasaan Allah dan kasih sayang-Nya.

Seandainya semua fakta dapat diketahui hikmahnya, maka dapat diyakini bahwa tujuan pendidikan nasional untuk membentuk manusia seutuhnya adalah bukan suatu ucapan kosong. Selain itu dapat diyakini bahwa pembahasan seperti ini akan dapat diterima oleh semua umat manusia yang beragama sebagaimana di Indonesia.

\section{SIMPULAN}

Pada dasarnya Internalisasi nilai tauhid harus dapat dilakukan pada semua materi sains. Untuk materi sains yang ada kaitannya dengan agama baik secara ekplisit maupun implisit maka internalisasi dapat dilakukan di awal, sedang proses dan akhir pembahasan materi sains. Internalisasi di awal dilakukan untuk membudayakan membaca dan menelaah agama (ayat atau hadis), membangkitkan motivasi, memberikan arahan, landasan dalam mempelajari sains. Internalisasi pada proses pembahasan materi sains dilakukan melalui integrasi langsung, yaitu dengan memadukan perspektif ilmiah dan agama. Internalisasi nilai tauhid di akhir pembahasan materi dimaksudkan agar melalui materi sains tersebut dapat membangkitkan kesadaran tentang anugrah dan kasih sayang, kebesaran dan kekuasaan, rasa syukur kepada Allah. Sedangkan untuk materi sains yang tidak diketahui kaitannya dengan agama maka internalisasi nilai tauhid hanya dapat dilakukan di awal dan akhir tanpa ada proses integrasi. di awal juga dilakukan tanpa harus membaca dan menelaah agama. Untuk materi sains yang bersifat anomali (seperti kasus air) dan materi-materi yang tidak disenangi terjadinya, misalnya gunung berapi maka sangat perlu penekanan pada hikmah (takdir Allah dengan segala hikmahnya). Keberhasilan internalisasi nilai tauhid pada materi sains atau dalam pembelajaran sains sangat ditentukan oleh faktor guru. Guru harus profesional dalam keilmuan materi sains dan harus memahami tentang agama (al-Qur'an dan hadis). Hal yang paling penting guru harus mampu menjadi suri tauladan dalam masalah akhlak (Akhlak kepada Allah, sesama manusia dan lingkungan), sehingga sosok guru sendiri dapat berperan sebagai model. UIN merupakan lembaga yang memungkinkan mencetak guru yang memiliki kemampuan tersebut. 


\section{DAFTAR PUSTAKA}

Amir, Dja'far. 1986. Ilmu Taubid. Cetakan ketiga. Jakarta : Ramadhani

Ardiansyah, M.A 2011. Proses Internalisasi Nilai. [on line]. Tersedia : www.kabar-pendidikan.blogspot.com, www. kmp- malang.com www.arminaperdana.blogspot.com [ 20 januari 2012]

Bagir, Z.A., Wahyudi, J., Anshori, A.(2005). Integrasi Ilmu dan Agama : Interpretasi dan Aksi. Bandung : Mizan

Departemen Agama. 1989. Al-Qur'an dan terjemahannya. Jakarta : Departemen Agama RI

Baru van Hoeve.

2002. Ensiklopedi Islam. cetakan kesepuluh. Jakarta : Ichtiar

Departemen P dan K. 1989. Kamus Besar Bahasa Indonesia. Jakarta: Balai Pustaka 2004. Ensiklopedi Nasional Indonesia.cetakan keempat.

Bekasi : Delta Pamungkas.

Departemen Pendidikan Nasional. 2008. Strategi Pembelajaran MIPA. Jakarta : Departemen Pendidikan Nasional.

Djahiri, A.K. 1996. Menelusuri Dunia Afektif : Pendidikan dan Moral. Bandung : Lab Pengajaran PMP IKIP Bandung.

Elmubarok, Z. 2009. Membumikan Pendidikan Nilai : Mengumpulkan yang terserak, Menyambung yang terputus dan Menyatukan yang tercerai. Bandung: Alfabeta.

Firdaus. 1979. Risalab Taubid. Cetakan ketujuh. Jakarta : Bulan Bintang

Hakim, A.A. dan Mubarok, J. 2008. Metodologi studi Islam. Bandung : Remaja Rosdakarya.

Hartono. 2011. Pengembangan Model Pendidikan Nilai Dalam Pembelajaran Iintegrasi Sains dan Agama di MA Darul Ulum Jombang. Desertasi Doktor SPs UPI Bandung : tidak diterbitkan.

Harun, M. Y. 2000. Kitab Tauhid. Cetakan ketiga. Jakarta : Al-Sofwa.

Hornby, A.S., Cowie, a.p., Gimson, A.C. (1986), Oxford advanced Learner's Dictionary of Current English. Great Britain : Oxford University Press.

Jamaluddin. 2010. Begini Seharusnya Menjadi Guru : Panduan Lengkap Metodologi Pengajaran Cara Rasulullah. Cetakan ketiga, Jakarta : Darul Haq

Kusnadi. 2000. Pengembangan Pembelajaran Integrasi Nilai-Nilai Taubid Dalam Pengajaran Geografi (Penelitian Tindakan Di Kelas I SMU 19 Kotamadya Bandung). Tesis PPS UPI Bandung : tidak diterbitkan.

Murdiono, M. 2010. Strategi Internalisasi Nilai-Nilai Moral Religius Dalam Proses Pembelajaran Di Perguruan Tinggi.[Online]. Tersedia : http://www.bing.com/search?q=strategi+internalisasi\&form=MSNH65 $\underline{\mathrm{Ex}=132 \& \mathrm{y}=16}$. [20 Januari 2012]

Riduansyah. 2000. Penerapan Model Pembelajaran Terpadu Antara Biologi Dan Imtaq Untuk Meningkatkan Hasil Belajar Siswa MA. Tesis pada FPS IKIP Bandung : tidak diterbitkan.

Rochman, C. 2010. Pengembangan Program Pembelajaran Untuk Meningkatkan Kemampuan Mahasiswa Calon Guru Fisika Dalam Menyusun Program 
Pembelajaran Yang Mengintegrasikan Nilai Agama Islam. Desertasi Doktor pada SPs UPI Bandung: tidak diterbitkan.

Rohmawati, S.N. 2010. Integrasi Nilai-Nilai Taubid Pada Matapelajaran Sains Di Sekolah Dasar Islam terpadu Hidayatullah Balong Yogyakarta. [online]. Tersedia : http://www.google.co.id/search?client=firefox-

a\&rls $=$ org.mozilla $\% 3$ Aen-US $\% 3$ Aofficial\&channel $=\mathrm{s} \& h \mathrm{l}=\mathrm{id} \&$ source $=$ hp\&q=integrasi + nilai + tauhid $\% 2 C+$ Rohmawati\&meta $=$

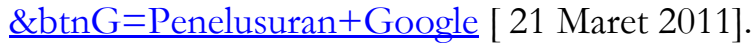

Romadlon, M.(2000). Pembelajaran Kimia Sub Baban Kajian Zat Aditif Pada Makanan Yang Terintegrasi Nilai-Nilai Agama.Tesis FPS UPI : Tidak diterbitkan.

Sabarkah, C.J.(2010) Pengembangan nilai-nilai agama melalui praktikum fermentasi karbohidrat ditinjau dari kemampuan Intertekstualitas, Jurnal Media Pendidikan :Pendidikan Keagamaan, volume XXV, nomor 3, 337-348

Sauri, S.(2005). Revitalisasi Pendidikan Sains dalam Pembentukan Karakter Anak bangsa untuk Menghadapi Tangtangan Global. [Online]. Tersedia: http://www.google.co.id/ search?client=firefox-a\&rls=org._[12 April 2011]

Tn. (1427 H/2006 H). Tafsir Al-Usyr Al-Akhir : Dari Al-Qur'an Al-Karim juz $(28,29,30)$ disertai Hukum-Hukum yang Penting Bagi Seorang Muslim

Wahab, Aziz: 2007. Pendidikan Pancasila dan Kewarganegaraan (PPKn). Jakarta: Penerbit Universitas Terbuka.

Witarto, A.B.(2009). Science and God : Warming Trend. [online]. Tersedia : http:/ / www.google.co.id/\#hl=id\&source=hp\&biw=1024\&bih=407\&q= Science+and+God:+A+Warming+Trend.+27+Maret+2009.+Oleh\%3A + Dr + Arief + budi + witarto $\% 2 \mathrm{C} \& b t n G=$ Penelusuran + Google\&aq=f\&aqi $\equiv \& a q l=\& o q=\& f p=$ cae13fe4ab903014 [15 maret 2011]. 